\title{
TO THE ISSUE OF ORGANIZATION THE OUTDOOR RECREATION FOR THE CITIZEN OF BIG CITIES IN THE MIDDLE DNIEPER REGION (ON THE EXAMPLE OF KYIV CITY)
}

\author{
'Oleksandr DMYTRUK, ${ }^{2}$ Maryna KULINICH \\ Taras Shevchenko National University of Kyiv, Ukraine \\ ${ }^{2}$ mai1989@ukr.net
}

\begin{abstract}
The article contains the researched features of organization outdoor recreation for citizen of big cities in the Middle Dnieper region (on example of Kyiv city). The territory of this region in all periods of history was attractive to the life of various tribes and peoples, and directly nowadays Middle Dnieper region is a place of development and growth of urban agglomerations. This research bases on conducting an online survey among 1117 respondents in Kyiv and on analysis of the collected data. Questions of online survey are focused on researching recreational needs of residents of large cities (on example of Kyiv city) with a focus on shortterm outdoor recreation. At the end of the article there is a proposed list of the main problems and recommendations for optimization of development water tourism in the Dnieper river basin. Attention is paid to the concepts "meadow park", "hydropark", "forest park" as the basis for the organization of comfortable places outdoor recreation for residents of big city in general and especially for families with children. There is presented interpretation of the concept "aquatic recreational landscape" from the standpoint of constructive-geographical principles of organization outdoor recreation.
\end{abstract}

Key words: Middle Dnieper, outdoor recreation, water tourism, constructive planning of recreation territories, meadow park, hydropark, forest park, aquatic recreational landscape

UDC: 379.83

\section{ДО ПИТАННЯ ЩОДО ОРГАНІЗАЦІЇ ВІДПОЧИНКУ НА ПРИРОДІ МЕШКАНЦІВ ВЕЛИКИХ МІСТ РЕГІОНУ СЕРЕДНЬОГО ПОДНІПРОВ'Я (НА ПРИКЛАДІ М. КИЄВА)}

\author{
'Олександр ДМИтРуК, ²Марина КУлІнІч \\ Київський начіональний університет імені Тараса Шевченка, Україна \\ 2mai1989@ukr.net
}

\begin{abstract}
Анотація: У статті досліджуються особливості організації відпочинку на природі мешканців великих міст регіону Середнього Подніпров'я (на прикладі м. Києва), оскільки територія саме цього регіону в усі періоди історії була привабливою для життя різних племен та народів, а безпосередньо в наш час Середнє Подніпров'я $\epsilon$ місцем розвитку і розростання міських агломерацій. Дане дослідження базується на проведенні онлайн-анкетування серед киян в чисельності 1117 респондентів та аналізі зібраних анкетних даних. Запитання онлайн-анкети сфокусовані на дослідженні рекреаційних потреб і вподобань мешканців великих міст (на прикладі м. Києва) з акцентом на короткостроковий відпочинок на природі. В кінці роботи наведено перелік основних проблем та рекомендацій по оптимізації розвитку водного туризму в басейні р. Дніпро. Приділено увагу сутності понять «лукопарк», «лісопарк», «гідропарк» як базису для організації комфортних місць відпочинку на природі для мешканців великого міста в цілому і зокрема для сімей з дітьми. Представлено трактування поняття «аквальний рекреаційний ландшафт» з позицій конструктивно-географічних засад організації відпочинку на природі

Ключові слова: Середнє Подніпров'я, відпочинок на природі, водний туризм, конструктивне планування території відпочинку, лукопарк, лісопарк, гідропарк, аквальний рекреаційний ландшафт
\end{abstract}

Удк: 379.83

Постановка проблеми. Територія Середнього Подніпров'я належить до земель, які здавна почали заселятися та освоюватися людьми. Сліди найдавнішої людської діяльності тут відносяться до доби палеоліту. Географічне розташування, сприятливі природні умови, родючі землі, відносно м'який клімат, наявність великої водної артерії (р. Дніпро) обумовили своєрідність історичного розвитку Середнього Подніпров'я. Ці землі були привабливими для різних племен та народів майже в усі періоди історії і саме тому на сьогоднішній день ми маємо і спостерігаємо розвиток і розростання міських агломерацій в регіоні Середнього Подніпров'я [3]. Адже в наш час всіх приваблює легке життя, без надмірних фізичних навантажень

(C) О. Дмитрук, М. Кулініч i виснажень, ці потреби 3 легкістю задовольняє всезростаючий процес урбанізації: автомобілі, красиві будівлі, все необхідне в величезних i яскравих торгівельно-розважальних центрах, новітні лікувальні засоби і заклади тощо - все це можна отримати в будь-який час доби. Однак ці зручності, нехай не прямо, але опосередковано точно, впливають на забрудненість атмосферного повітря, поверхневих вод, грунтів тощо, що в свою чергу веде до зростання чисельності i різновидів захворювання не лише мешканців міських територій, які плюс до всього вище сказаного ведуть ще й малорухливий спосіб життя, а й до зниження рівня здоров'я усього населення планети. Ось чому вже в наш час i в майбутні роки, що прийдуть, люди хочуть i хотітимуть 
наблизитись до незміненої або хоча б мало зміненої первозданної природи.

В оточенні власноруч створеного «комфорту» людина починає почувати себе в клітці, за гратами умовностей, повинностей тощо. Мабуть, кожен дорослий, який попав у цей конвеєр сучасного життя, через пару років задоволення від самостійності починає думати про те, щоб втекти від людей, де б не було Інтернету, телефонів, автомобілів, різноманітної техніки тощо. Тобто сучасні особливості і можливості роботи людини, перехід на постіндустріальний етап розвитку суспільства, шалений темп життя великого міста та високий рівень його технологізації призводять до психологічного навантаження на людину, тому постає питання про необхідність організації відпочинку мешканців цих міст від вище згаданої метушні, надмірного впливу високих технологій за для умиротворення, віднаходження спокою і душевної рівноваги, гармонії жителями цілодобово працюючої машини під назвою «велике місто». I цей спокій, цю гармонію людина може знайти в природі, в тісному контакті 3 нею, адже сама є їі невід'ємною частиною від початку свого існування.

Мета роботи - представити та проаналізувати особливості організації та бачення свого відпочинку жителями великих міст регіону Середнього Подніпров'я в цілому та на природі зокрема (на прикладі мешканців міста Києва).

Виклад основного матеріалу. Основою даного дослідження $є$ результати онлайн-анкетування. Онлайн-анкета була спеціально розроблена 3 метою дослідження рекреаційних потреб і вподобань мешканців великих міст (на прикладі м. Києва) 3 акцентом на короткостроковий відпочинок на природі. Анкета складається з 25 запитань, 5 з яких орієнтовані на збір особистих даних про респондентів, а 20 безпосередньо стосуються їх рекреаційних вподобань. Всі запитання послідовно і логічно об'єднані в чотири окремі блоки: відомості про респондентів; їх загальні рекреаційні вподобання; питання щодо безпосереднього відпочинку на природі; проблеми i перспективи (на думку респондентів) розвитку водного туризму в Україні. Зміст запитань безпосередньо відповідає темі дослідження, а самі запитання сформовані у короткій, чіткій, лаконічній і зрозумілій формі для будьякого респондента.

В онлайн-опитуванні взяли участь 1117 мешканців міста Києва, що розподілені на дві вікові групи: до 25 років у кількості 544 особи та 25-40 років у кількості 573 особи. 3 них жінки становлять групу із 716 осіб, а чоловіки - 401 особа. За сімейним станом 372 респонденти знаходяться в шлюбі. За родом зайнятості 172 респонденти належать до категорії студентів, 725 - службовці, робітники, 136 підприємці, 84 - безробітні. Окрім того 54\% опитуваних найчастіше відпочинок проводять 3 друзями, 38\% - із сім'єю і 8\% - наодинці. В той же час $77 \%$ опитуваних приваблює активний відпочинок, а 23\% віддають перевагу пасивному відпочинку. Тому зрозумілим є й те що, 59\% респондентів найдоцільнішою порою року для відпустки вважають літо, 19\% - зиму, 14\% - весну та лише $8 \%$ вважають, що найбільш підходящою порою року для відпустки є осінь.

Серед запропонованих в анкеті видів відпочинку були культурно-пізнавальний, пляжний відпочинок, відпочинок 3 наметом біля води, піші прогулянки, курортно-оздоровчий, лижний відпочинок, екстремальний відпочинок, відпочинок 3 наметом в лісі, сільський зелений туризм. Дані про вподобання респондентів в даному питанні представлено на рис. 1 .

Наступним пунктом анкети була тривалість короткочасного відпочинку киян: 1 день, до 3-х днів, до 5-ти днів. Так, 86 осіб назвали 1 день, 649 - до 3-х днів і 382 - до 5-ти днів.

На запитання «Де найчастіше Ви проводите вихідні?» 38\% відповіли «вдома», по 20\% - «в розважальних закладах (ТРЦ, дискотеки, клуби)» та «на природі», 22\% - «кінотеатри, театри, музеї» (рис. 2).

Тобто, відпочинок на природі займає чи не останнє місце серед можливих варіантів відпочинку на вихідних у киян.

Такий стан речей викликає занепокоєння, адже на запитання «Як часто Ви бажаєте відпочивати на природі?» 32\% відповіли - раз на два тижні, 27\% раз в місяць, 22\% - кожні вихідні, $18 \%$ - раз на рік і лише 1\% респондентів - не бажає відпочивати на природі взагалі (рис.3).

При виборі місця відпочинку $36 \%$ опитаних киян керуються орієнтацією на туристсько-рекреаційні ресурси, 25\% вказують, що визначальним для них фактором при виборі місця відпочинку $\epsilon$ вартість, 22\% опираються на рекомендації родичів, друзів, знайомих, і 17\% зазначають, що для них визначальним фактором при виборі місця відпочинку є комфорт.

На рисунку 4 наведено діаграму, що відражає те, які природні компоненти найбільше привертають увагу рекреантів (киян) при виборі місця відпочинку.

Тобто кияни вважають водні об'єкти найбільш атрактивними компонентами природного середовища. Хоча лише $18 \%$ респондентів вказали, що брали участь у сплавах по річках, і лише $33 \%$ зазначили, що в майбутньому хотіли б взяти участь у сплаві. Всі інші респонденти вказали, що полюбляють купальнопляжний відпочинок без використання складних технічних засобів (човни, катамарани, вітрильники тощо).

В той же час 93\% опитаних киян вважають за необхідне проведення конструктивного планування території біля водойм в приміській зоні за для створення комфортних місць регулярного відпочинку на природі. Серед них 93\% 153 особи (14\%) запевнили, що відвідували б такі місця кожні вихідні, 277 осіб (26\%) - раз на 2 тижні, 296 осіб (28\%) - раз в місяць і 334 особи (32\%) - декілька раз на рік.

На запитання «Які емоції у Вас викликає відпочинок біля води?» більшість респондентів обрали наступні варіанти: задоволення, спокій, 


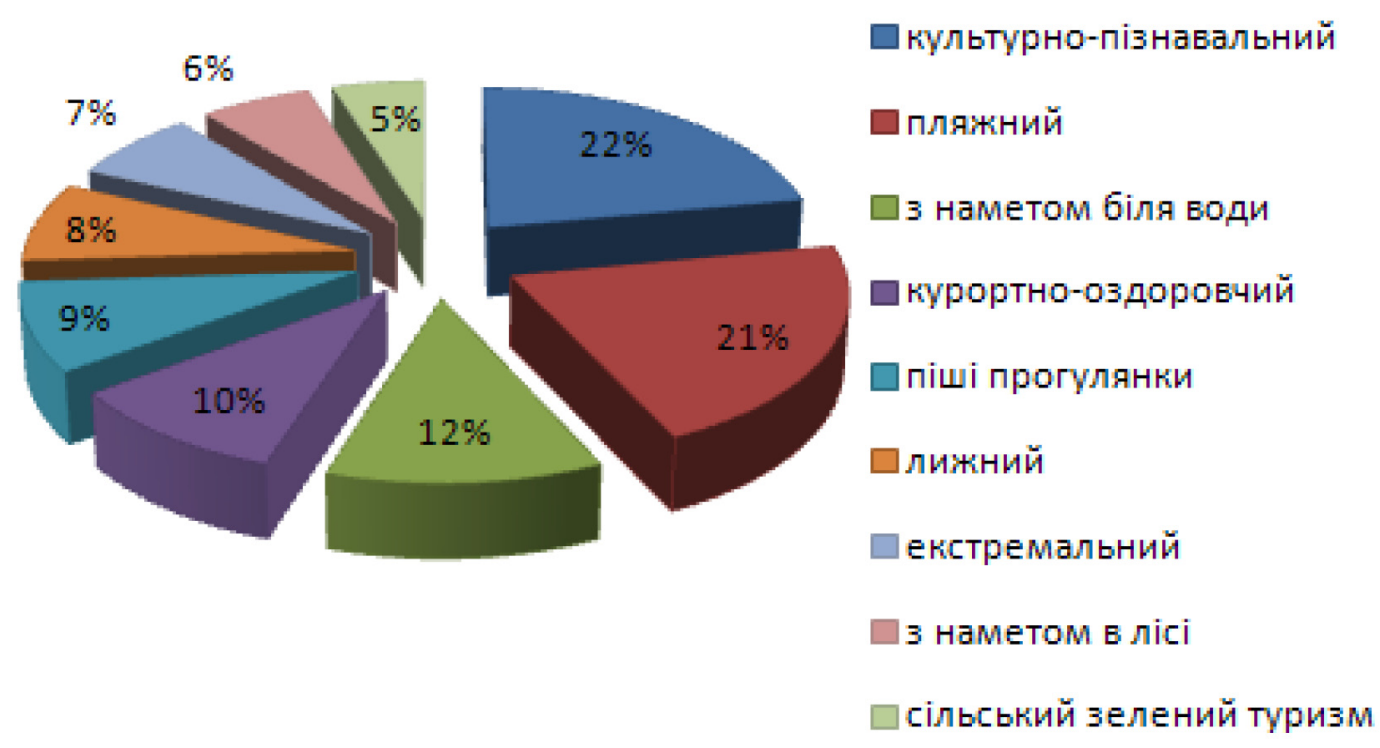

Рис. 1. Вподобання мешканців міста Києва щодо видів відпочинку

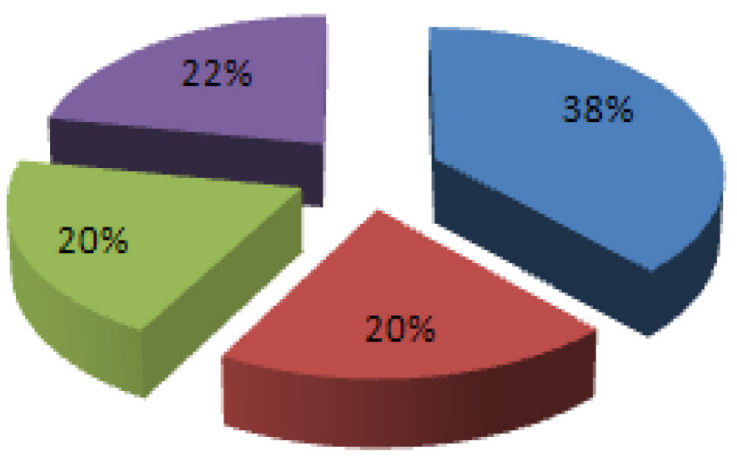

\author{
вдома \\ п ТРЦ, дискотеки, клу6и \\ на природі \\ вінотеатри, театри, музеї
}

Рис. 2. Специфіка організації відпочинку киян на уїк-енд
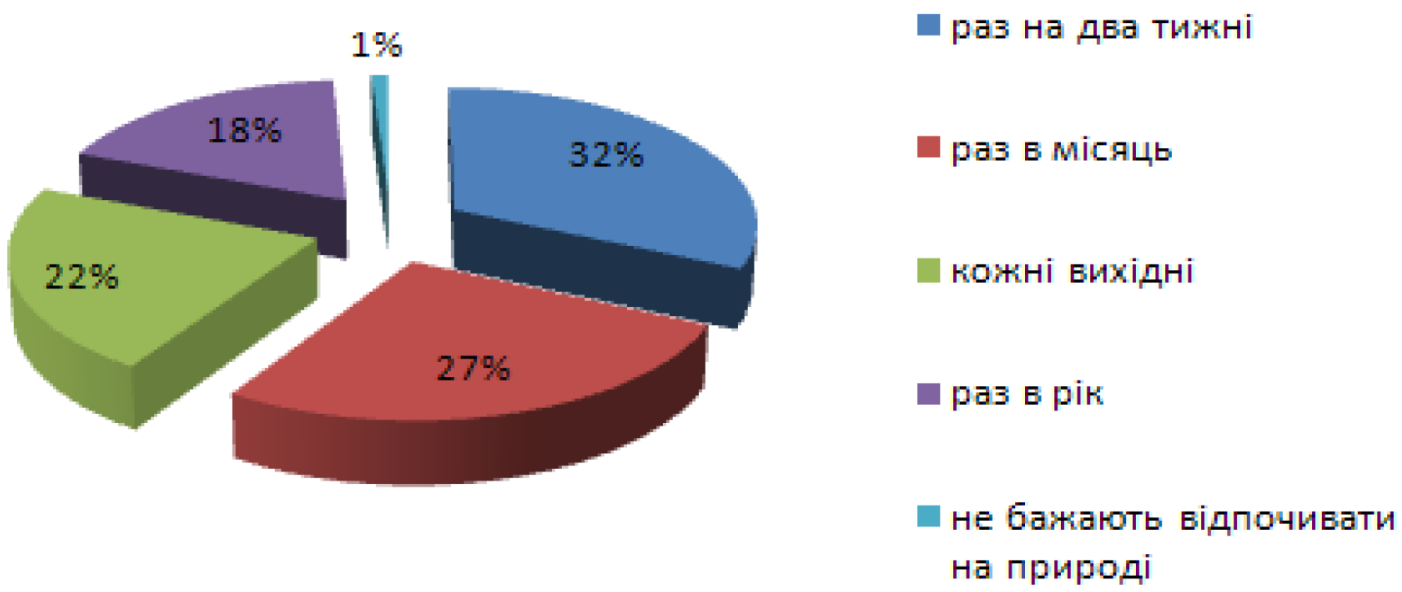

Рис. 3. Бажання киян щодо відпочинку на природі (частота відпочинку) 

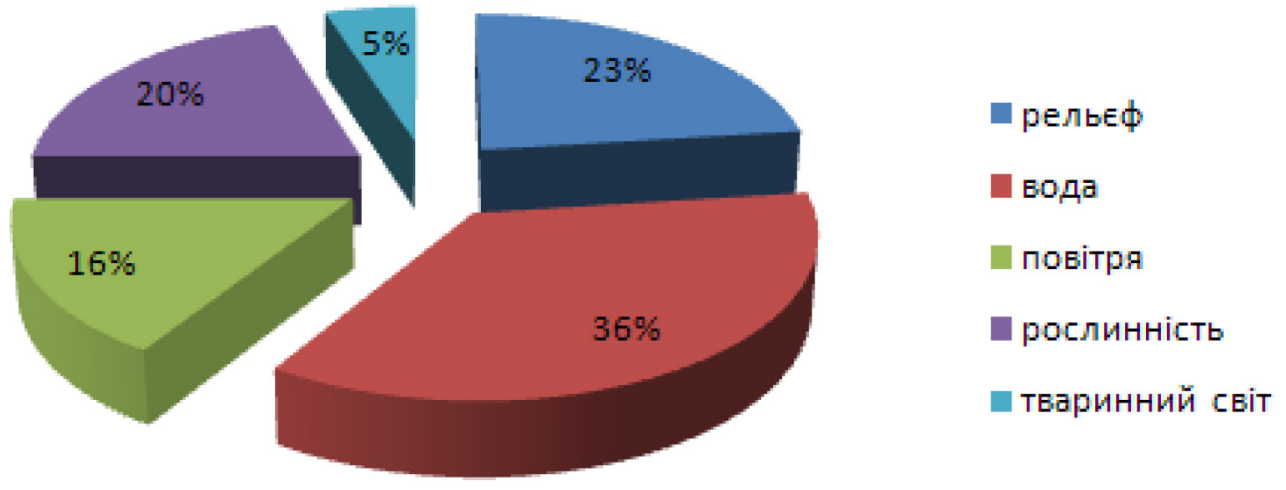

Рис. 4. Ієрархія природних компонентів за ступенем атрактивності для киян

мрійливість, прилив життєвої енергії, і лише 211 осіб додали до цього переліку ще й задумливість, а відповіді 17 осіб взагалі були кардинально відмінними від інших респондентів: самотність і відчуття страху.

В ході опитування кияни зазначили власну думку стосовно основних проблем або перепон на шляху розвитку водного туризму в Україні. Серед них наступні:

- занедбаність річок та територій навколо них, забрудненість водойм не лише хімічними речовинами, а й твердими побутовими відходами;

- недостатня кількість спеціально облаштованих місць для відпочинку;

- висока вартість відвідування уже наявних облаштованих місць відпочинку на берегах Дніпра;

- передання у приватну власність та забудова прибережних територій, що закриває доступ до привабливих місць відпочинку та перекриває розвиток всієї берегової лінії, як рекреаційної території;

- недостатня увага до туристичних проектів та їх недостатнє фінансування;

- відсутність розумного менеджменту та маркетингу стосовно раціонального природокористування та ландшафтного планування територій;

- відсутність чіткого алгоритму дій спрямованих на розвиток i підтримку даного виду туризму в Україні тощо.

Основні ж рекомендації і побажання стосовно розвитку водного туризму в басейні річки Дніпро виглядають наступним чином:

- державна підтримка і популяризація водного туризму;

- пошук інвесторів для організації спеціалізованих водно-рекреаційних парків;

- формування молодіжного волонтерського руху 3 метою привертання уваги до рівня забруднення та організації очищення водойм, прибирання їх берегових смуг;

- демонтаж незаконних забудов та «визволення» незаконно привласнених територій берегових смуг водних об'єктів;

- створення цікавих екскурсійно-розважальних та організація сучасних водних розваг в межах спеціально об лаштованих водно-рекреаційних зон відпочинку, а також контроль за доступністю для середньостатистичного українця цін на відвідування таких місць;

- створення стійкого інформаційно-позитивного образу водного туризму на Дніпрі, розробка i запуск реклами за для інформування, інтригування та запрошення до активної участі потенційних рекреантів.

Відповідаючи на розгорнуті запитання щодо перепон і стимулів розвитку водного туризму в Україні багато респондентів згадали про круїзи по Дніпру, висловили бажання щодо формування пляжів двох типів: природа, спокій, усамітнення 3 одного боку і атракціони, розважальні заклади 3 іншого.

Варто зазначити, що Україні з радянських часів у спадщину залишились спеціально обладнані в межах великих міст місця для рекреації і відпочинку у вигляді лукопарків, гідропарків, лісопарків.

Лукопарк - це впорядкована територія лук, що характеризується перевагою відкритих лучних просторів, які становлять більше половини площі лукопарку, а інша частина відводиться під декоративні насадження та водойми. Оптимальне співвідношення лучних територій, декоративних насаджень та водойм - 5:2:1 [1, с. 33]. Гідропарк упорядкована територія (організований простір), що характеризується перевагою водойм як найважливіших об'єктів організації літнього відпочинку. Співвідношення водойм, насаджень i луків становить 2:1:1 [1, с. 15]. Лісопарк упорядкована територія лісу, призначена для короткочасного відпочинку та перетворена шляхом поступової іii реконструкції на певну ландшафтнопланову систему [1, с. 32]. Проте вся ця спадщина (у вигляді лукопарків, лісопарків, гідропарків) наразі знаходиться в незадовільному стані і не $є$ привабливою для сімейного відпочинку 3 дітьми. Проте сама ідея $\epsilon$ цікавою, тому заслуговує на подальше опрацювання і розбудову в світлі умов і можливостей життя сучасного суспільства.

Враховуючи те, що більшість респондентів визначили воду, як найбільш привабливий елемент 
природного ландшафту i найбільш вагомий чинник, що впливає на вибір місця відпочинку, можна говорити про облаштування аквальних рекреаційних ландшафтів поблизу великих міст в регіоні Середнього Подніпров'я i не тільки. Поняття «лукопарк», «лісопарк», «гідропарк» є дуже близькими до поняття «аквальний рекреаційний ландшафт», хоча якщо взяти окремо кожний термін, то вони не передають особливостей аквального рекреаційного ландшафту в повній мірі. Адже аквальний рекреаційний ландшафт - це комплексне функціональне поєднання ділянок водного простору і суші, яке піддається антропогенному управлінню, плануванню i реконструкції, 3 метою створення культурно облаштованих, естетично-привабливих місць відпочинку відповідно до різнопланових та специфічних рекреаційних потреб населення (організація відпочинку для дітей, дорослих, людей $з$ обмеженими фізичними можливостями) за для покращення здоров'я, позитивно-емоційного збагачення та розвитку особистості.

Висновки. Кияни мають інтерес до відпочинку на природі, але як мешканці великого міста в той же час цінують свій комфорт, тому бажають, щоб місця для такого відпочинку були чітко сплановані 3 урахуванням розмірів особистого простору людини, розмежування прибережної території i акваторії на спеціалізовані зони відпочинку, створення мінімальних умов комфорту: вбиральні, сміттєві баки, окремі місця для пікніків та дитячих ігор, окремі місця для купання, риболовлі та водного відпочинку 3 використанням технічних засобів (водні велосипеди, катамарани, човни, парусники) тощо. Враховуючи те, що респонденти називають водні об'єкти найбільш атрактивними компонентами природного середовища, в майбутньому необхідно більш детально розглянути можливості проведення конструктивного планування території біля водойм в приміській зоні з метою створення комфортних місць і умов відпочинку для мешканців не лише міста Києва, а й інших густозаселених міських i приміських територій.

Можливо, слід дати більше можливостей приватним підприємцям для створення місць організованого відпочинку на природі. Вони б проявили творчість, запозичили б досвід інших країн, прагнули б задовольнити бажання своїх споживачів. Адже за законами ринкової економіки саме попит породжує пропозицію.

\section{References:}

1. Bejdik O. O. Slovnik-dovìdnik z geografïï turizmu, rekrealogiï ta rekreacìjnoï geografïi [Geography of tourism, recreology and recreational geography: reference dictionary]. Kyiv, 1998, 130 p. (In Ukrainian).

2. Dmitruk O. U. Ekologičnij turizm: sučasnì koncepciï menedžmentu ì marketingu. [Ecological tourism: modern management and marketing concepts]. Kyiv, 2004, 192 p. (In Ukrainian).

3. Rudič T. O. Naselennâ Seredn'ogo Podnìprov'â İ-İ̀ tisâčolìttâ za materìalami antropologiii [Population of the Middle Dnieper in the I-II Millennia: Anthropological Evidence]. Kyiv, 2014, 298 p. (In Ukrainian). 